Original Research

\title{
Spatiotemporal Variability of Temperature and Its Extremes Over an Agro-Ecological Region of Tamil Nadu, India
}

\author{
B. Ganeshkumar*, GVT Gopala Krishna \\ Department of Civil Engineering, PSNA College of Engineering and Technology, Dindigul, Tamil Nadu, India
}

Received: 19 September 2019

Accepted: 26 December 2019

\begin{abstract}
Temperature data from 14 stations were used to explore the spatiotemporal variability of temperature and its extremes for the period 1960-2018 in the Cauvery River Delta (CRD) area, an agro-ecological region of Tamil Nadu State, India. This investigation was carried out by using spline interpolation method, linear regression and Mann-Kendall test with a Sen's slope estimator. Results indicated that the spatial patterns and temporal trends of annual and seasonal temperature showed an upward trend in most parts of the CRD region. The spatial changes of mean temperature at annual and seasonal scale were similar and showed an upward trend. Extreme temperature indices showed an increasing trend throughout the area. This investigation was carried out for a period of six decades from the year 1960. The CRD region exhibited a warming trend after the 1980s. Temperature variability over this region was witnessed by the global and regional level climate warming. These variability conditions would influence the growth and life cycle of agricultural crops. The results of this investigation could support decision makers and authorities to activate adequate irrigation and crop-changing strategies in order to protect vulnerable ecosystems and environmental conditions of the CRD region.
\end{abstract}

Keywords: temperature variability, Cauvery River Delta, regional climate, extreme indices

\section{Introduction}

Climate is a crucial factor influencing the ecosystem. Variation of climate at both spatial and temporal scales plays a primary role in the eco-environmental changes of an agricultural region. In recent times, the study of regional climate variability has drawn special attention among research workers [1]. Temperature and rainfall

*e-mail: bgeekay@gmail.com are the two important meteorological variables widely involved in climate variability studies [2, 3]. Any change in these variables could lead to the risk of food production being greatly affected [4]. In particular, temperature is considered (i) to contribute the terrestrial environmental phenomena such as drought and (ii) as a variable connected with geographical space; hence its regional level observation becomes necessary [5, 6]. And also it affects ecological and environmental parameters of a concerned region [7, 8]. Subsequently, there is a growing importance to investigate the variability trends of temperature and its extremes - 
especially in an agricultural region - for practicing sustainable agricultural production and balancing ecoenvironmental conditions [9].

In India, Tamil Nadu was among the few states that joined the Green Revolution in the 1970s. Tamil Nadu's Cauvery River Delta (CRD) region is popularly known across the country as the 'rice bowl of the state' for its significant rice production. The region has a surface area of $60.2 \%$ under cultivation, and around $73 \%$ of people are involved in agriculture and its associated livelihood activities [10]. Nevertheless, from the past two decades, the composition and quality of the agricultural sector have been experiencing significant changes. The monsoon-dependent region experiences a cycle of alternating drought and floods, which are more prevalent. Over the past few years, this area has been afflicted by water shortages during summer and submerges in monsoon. Because of the rising levels of global warming and changing patterns of land use, trends in climate change became uncertain [11]. Due to this, extreme climate events have been posing difficulties in local agriculture preparation and its implementation phases. Understanding such events through this investigation shows a way to make the responsive and adaptive strategies to support the farmers at both regional and local levels.

Several scientists have discerned climate trends; however, only a few studies have examined temperature characteristics of delta areas that are susceptible to heatrelated effects [12]. Variability in rate of temperature over delta districts was documented as $0.4^{\circ} \mathrm{C}$ per year [13]. Another study addressed the statistical significance of annual temperatures for the coastal districts of the delta region [14]. On using the outputs of a regional climate model, an increasing trend of temperature was reported at both seasonal and annual scales [15]. The expected increase in maximum and minimum temperature at the end of the 2020s was estimated as $0.8^{\circ} \mathrm{C}$ [16]. The available studies over the CRD region have concentrated on the analysis of climate change and its impacts over production of rice [17-19]. Few studies have used model-based temperature projections instead of field observations for the historical years [20-22]. Studies conducted on temperature trends so far are at a macro scale, which is not useful for locallevel understanding. Analysis of seasonal trends of temperature change instead of annual scale is essential for promoting agricultural activities, including the analysis on spatio-temporal variability of temperature. In light of the literature review, it was clear that the study of temperature variability in the CRD region has not yet been done so far. Hence, the present investigation aimed to analyze the regional variability of temperature and its extreme trends both in spatial and temporal contexts based on diurnal temperature data recorded for the years 1960-2018 in the CRD region. The salient objectives of this investigation are to examine (1) variability of seasonal temperature in seasonal, annual and decadal scales and (2) variability of temperature extreme indices throughout the study period.

\section{Study Area}

In the present investigation, the CRD region is considered as the study area, covering $1.41 \times 10^{4} \mathrm{~km}^{2}$ of the geographical area of Tamil Nadu State, India. The CRD region is located between 10.00-11.50 north latitudes and $78.15-79.90^{\circ}$ east longitudes. This area is fertile and widely utilized for the cultivation of paddy [23]. As a semi-arid climatic zone, the region experiences four seasons: (i) cold-weather period (CWP - January to February), (ii) hot-weather period (HWP - March to May), (iii) southwest monsoon (SWM - June to September) and (iv) northeast monsoon (NEM - October to December) as per the classifications of the Indian Meteorological Department (IMD) [24]. This entire region is experiencing notable variation in the mean daily maximum and minimum temperatures [25]. The annual mean temperature ranges from $22^{\circ} \mathrm{C}$ to $33^{\circ} \mathrm{C}$, with June being the warmest month and January the coldest. During HWP, mean maximum and minimum temperatures are recorded as $37^{\circ} \mathrm{C}$ and $25^{\circ} \mathrm{C}$, respectively. In CWP, it reaches up to a maximum temperature of $32^{\circ} \mathrm{C}$ and minimum of $20^{\circ} \mathrm{C}$. Mean annual rainfall of the region (2000-2015) is $1052 \mathrm{~mm}$, ranging from $761.5 \mathrm{~mm}$ to $1396 \mathrm{~mm}$ in which $80 \%$ of the parts receive mainly during the months between October to December. The Cauvery River divides the CRD region flowing from a northwesterly to southeasterly direction. Fig. 1 illustrates the location of the study area and temperature monitoring stations.

\section{Data and Methods}

Temperature data used in the present investigation were obtained from the India Meteorological Department, Pune for the period 1960-2002 and the Tamil Nadu State Surface and Groundwater Data Centre in Chennai for the period 2003-2018. Diurnal temperature data were subjected to a homogenization process in order to identify reliable observation stations. The locations of all available monitoring stations are shown in Fig. 1. The obtained data were averaged into monthly, seasonal and annual scales for every reliable monitoring station.

Spline is a geostatistical interpolation method used by many researchers for analyzing spatial trend variability of meteorological data. This technique is well known for its robustness in allowing statistical values and uncertainties of predicted values in the formation of trend surfaces. The spline method predicts the spatial coverage of temperature accurately - especially for an agricultural region [26], while geostatistical tools of ArcGIS software were used to perform spatial 

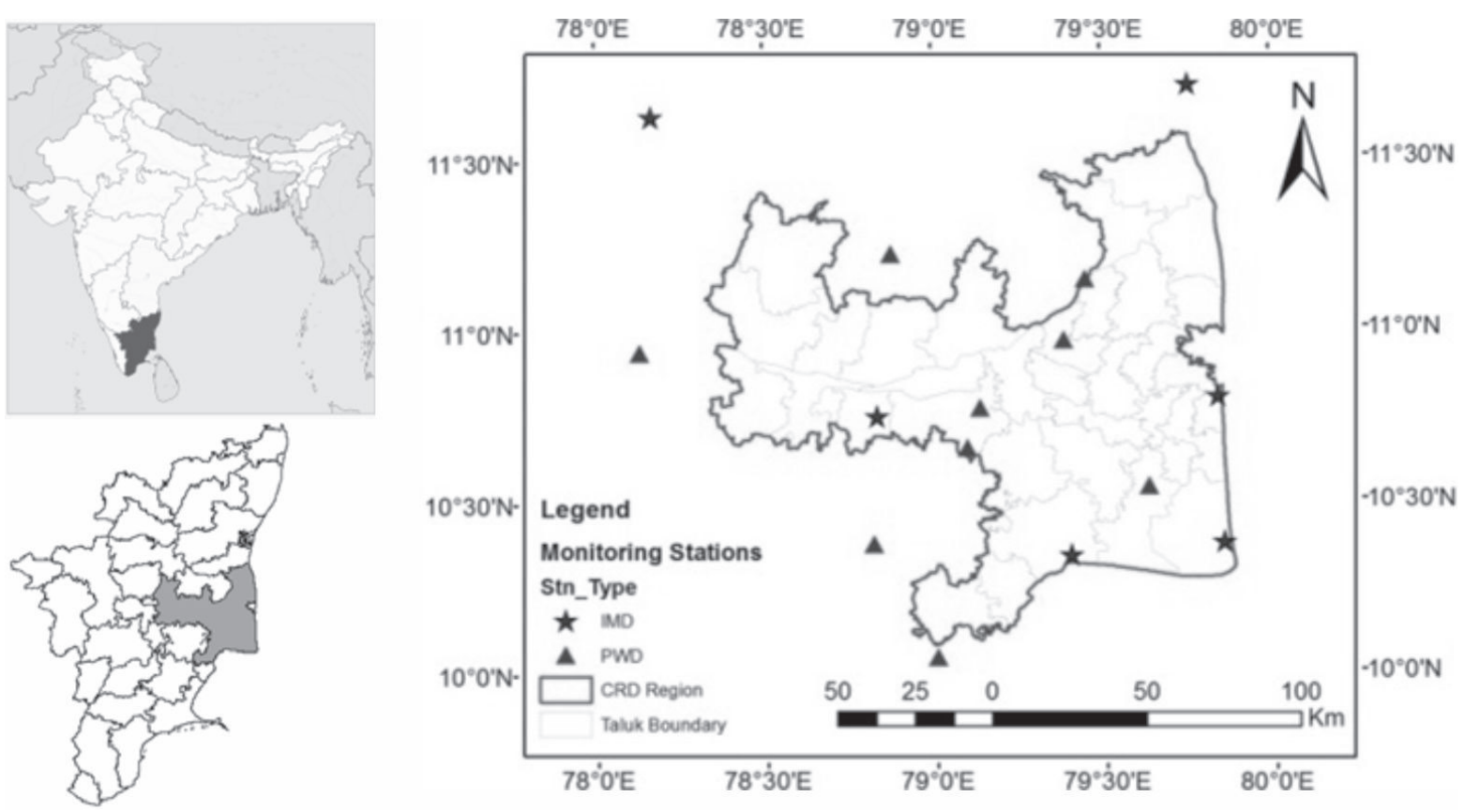

Fig. 1. Study area and locations of temperature-monitoring stations.

interpolation over temperature data [27]. Regression and moving average methods were employed to investigate the temporal behavior of temperature $[28,29]$. The moving average method is well suited for handling statistical series of meteorological data [30]. In this present work, variability trend was calculated based on five-year moving average whereas long-term variability trend was calculated using the linear regression method.

The temperature extreme indices used in the present investigation are given in Table 1 [31], which were calculated from the daily temperature data. Trend prediction of the annual and seasonal scale was done through the Mann-Kendall test (MKT) [32]. Theil and Sen's estimator (TSSE) Test was used for estimating the magnitude of variability trend [33]. The confidence level at 5\% significance was used to test the statistical significance. ProUCL software was used to perform statistical operations over temperature data.

\section{Results and Discussion}

Spatiotemporal Trends of Mean Temperature

The seasonal temperature variability in the CRD region for the period 1960-2018 was illustrated in Fig. 2. The variability was based on the normal temperature calculated for a 30-year baseline period between 1960 and 1990. Fig. 2 shows that it was seen that the first two decades received colder seasonal temperatures followed by relatively warmer seasonal temperatures. The temperature in CWP showed a rising trend after 1987, and in most years it was relatively warm, with an average increase of $1.36^{\circ} \mathrm{C}$ with the exception of 1994 (Fig. 2a). After 1979, the HWP temperature showed a continuous changeover trend (Fig. 2b). This season was so warm after 1986. The maximum increase was seen in 2010 of about $2.26^{\circ} \mathrm{C}$

Table 1. ETCCDI temperature extreme indices.

\begin{tabular}{|c|c|}
\hline Notation & Description (units in parenthesis) \\
\hline $\mathrm{TXx}$ & Maximum of monthly maximum temperature $\left(\right.$ in $\left.{ }^{\circ} \mathrm{C}\right)$ \\
\hline $\mathrm{TXn}$ & Minimum of monthly maximum temperature $\left(\right.$ in $\left.{ }^{\circ} \mathrm{C}\right)$ \\
\hline $\mathrm{TNx}$ & Maximum of monthly minimum temperature $\left(\right.$ in $\left.{ }^{\circ} \mathrm{C}\right)$ \\
\hline $\mathrm{TNn}$ & Minimum of monthly minimum temperature $\left(\right.$ in $\left.{ }^{\circ} \mathrm{C}\right)$ \\
\hline $\mathrm{DTR}$ & Diurnal temperature range (in days) \\
\hline SU25 & Count of High temperature days with $>25^{\circ} \mathrm{C}($ in days) \\
\hline CSDI & Cold spell duration indicator - Annual count of days with at least 6 consecutive days (in days) \\
\hline WSDI & Warm spell duration indicator - Annual count of days with at least 6 consecutive days (in days) \\
\hline
\end{tabular}



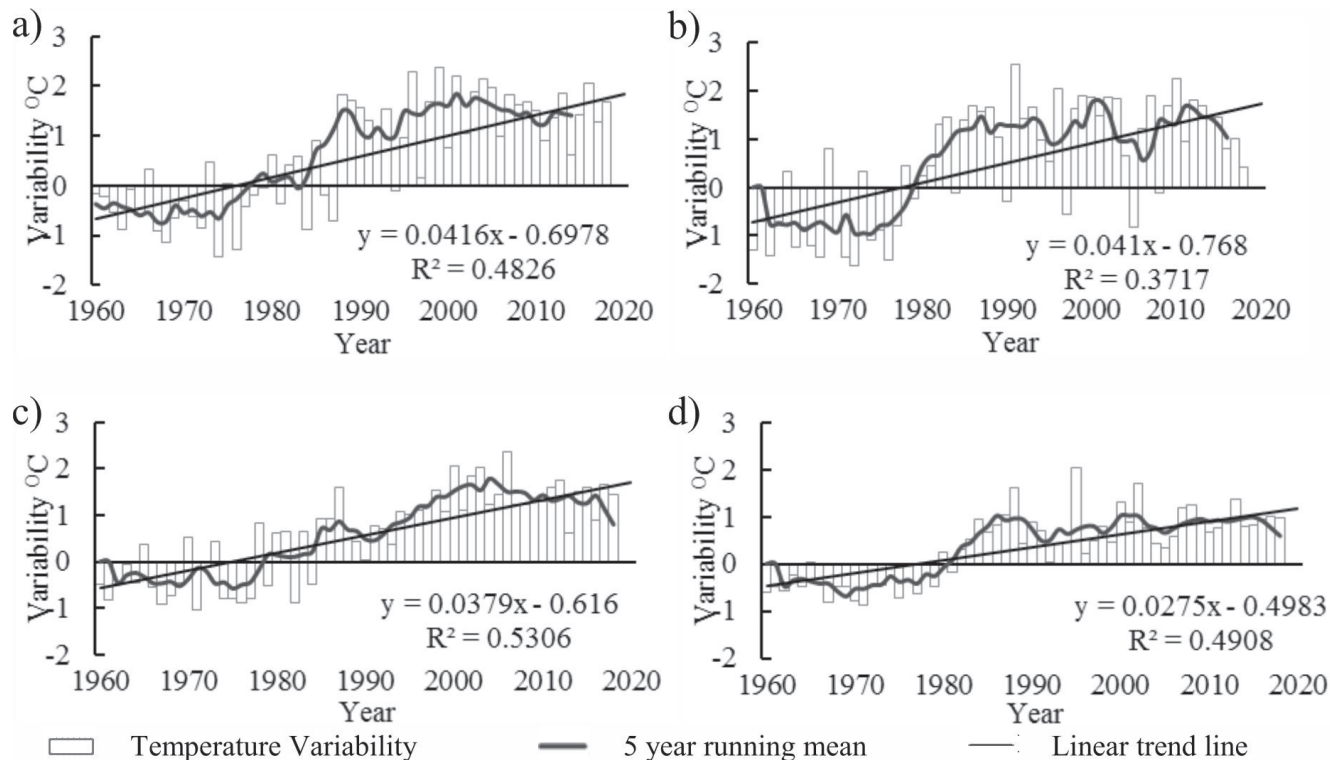

Fig. 2. Variability of mean seasonal temperature in the CRD region for 1960-2018 (baseline period: 1960-1990). a) Temporal variability in CWP, b) Temporal variability in HWP, c) Temporal variability in SWM, d) Temporal variability in NEM.

above normal. During SWM season, an upward trend was observed after 1993 with an observed average rise of $1.41^{\circ} \mathrm{C}$ (Fig. 2c).

The NEM season showed cold trends from 1960 to 1979 and warm trends from 1980 to 1990, and increasing warm trends in 1994 to 2018 (Fig. 2d). The upward linear trend was demonstrated by trend analysis over seasonal temperature (Fig. 2a-d). The CWP and HWP seasons showed the tendency rate of $0.42^{\circ} \mathrm{C}$ and $0.41^{\circ} \mathrm{C}$ increase per decade with a $\mathrm{P}<0.001$ significance level. The SWM season had $0.38^{\circ} \mathrm{C}$ per decade increase with $\mathrm{P}<0.001$ significance level. A moderate significant increasing trend of $0.27^{\circ} \mathrm{C}$ per decade was identified at $\mathrm{P}<0.05$ significance level for the NEM season. These trends showed a significant increase in temperature during all four seasons.

The annual temperature exhibited consistent fluctuations between cold and warm and vice versa, similar to the seasonal temperature (Fig. 3). For the period between 1985-2018, there was an average increase of $0.89^{\circ} \mathrm{C}$ over normal. The rate of upward trend was $0.39^{\circ} \mathrm{C}(\mathrm{P}<0.001)$ per decade. It was apparent

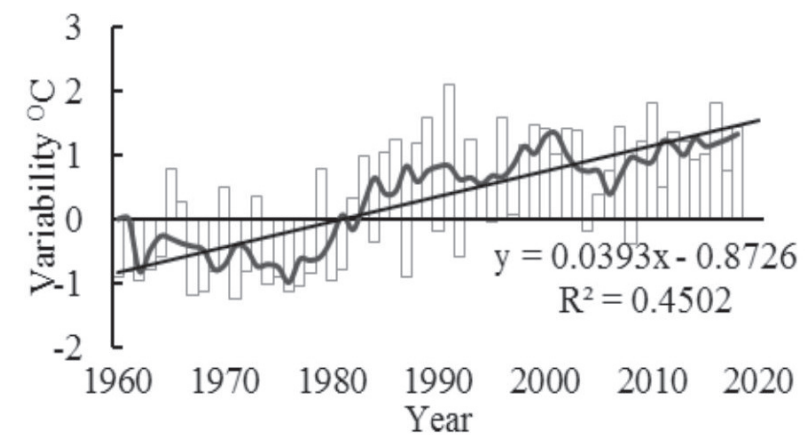

Fig. 3. Variability of annual mean temperatures. that after the second decade of the study period, the temperature showed an upward trend at both seasonal and annual scales. Fig. 4 depicts the interdecadal variability of seasonal temperature of the CRD region. CWP and HWP averaged an increase of $0.4^{\circ} \mathrm{C}$ in all decades since the 1980s. The temperature was constantly warm over the next four decades, while NEM was comparatively colder. NEM and CWP showed greater variability in comparison to all other seasons. The CRD region faced the same rise of $1.2^{\circ} \mathrm{C}$ in HWP over the last 3 decades while SWM demonstrated a notable fluctuation.

Spatial changes in the CRD region between 1960 and 2018 for seasonal temperatures are presented in Fig. 5. The CRD region was divided into three zones for the purpose of detailed analysis. Zone I covered all the coastal districts, whereas the central and western parts of the CRD region were covered by Zones II and III respectively. The seasonal temperature of CWP increased at different rates in the majority of CRD regions and its uptrend rates ranged from 0.01 to $2.5^{\circ} \mathrm{C}$ (Fig. 5a). The temperature over $91 \%$ of Zone II taluks

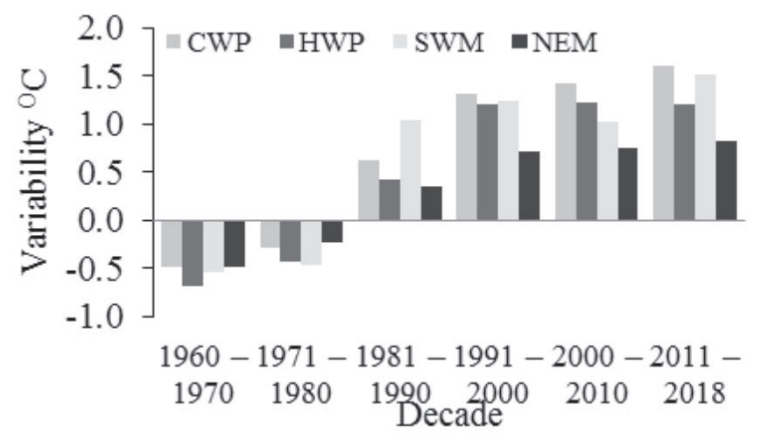

Fig. 4. Decadal variability of seasonal temperatures. 
a)
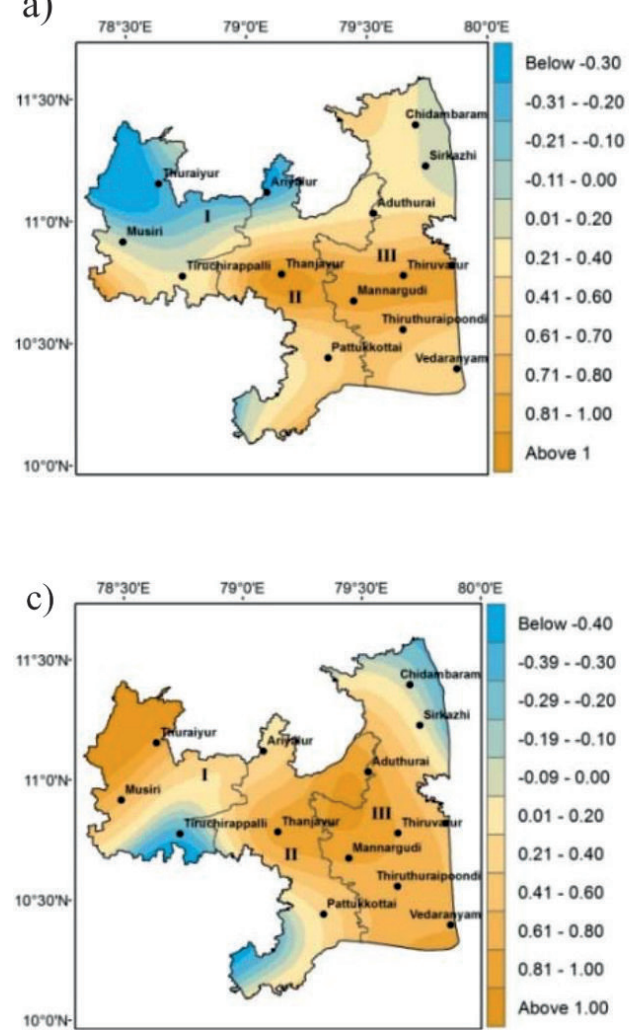
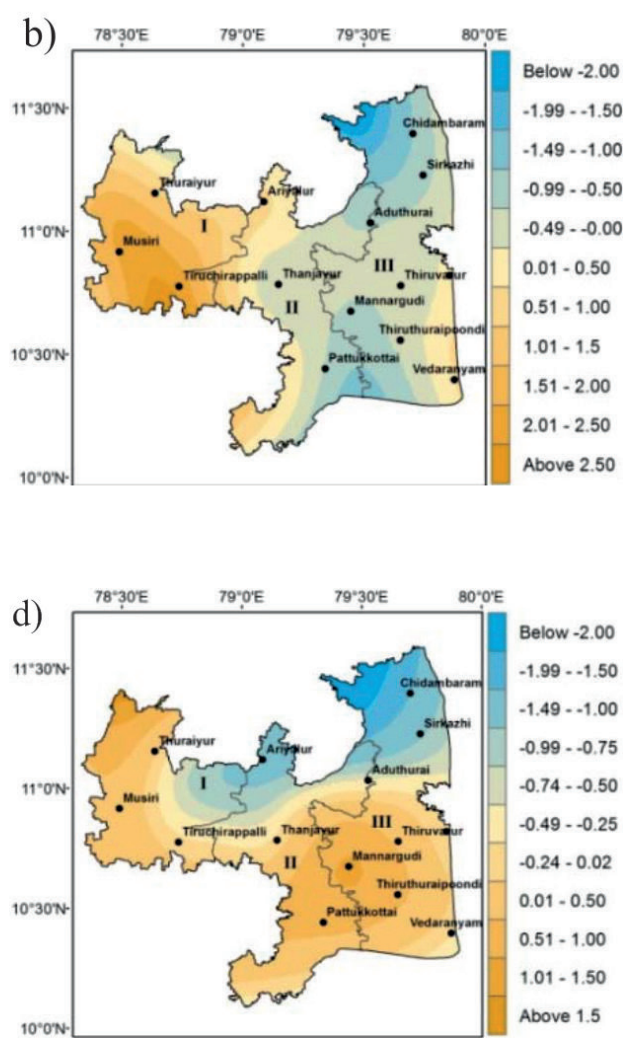

Fig. 5. Spatial distribution of temperature variability at seasonal scale in the CRD region during 1960-2018 (baseline period: 1960-1990). a) Spatial variability in CWP $\left({ }^{\circ} \mathrm{C}\right.$ per decade), b) Spatial variability in HWP $\left({ }^{\circ} \mathrm{C}\right.$ per decade), c) Spatial variability in SWM $\left({ }^{\circ} \mathrm{C}\right.$ per decade), d) Spatial variability in NEM $\left({ }^{\circ} \mathrm{C}\right.$ per decade).

and $97 \%$ of Zone III taluks showed a rise of above $1^{\circ} \mathrm{C}$ across east and west and gradually cooled along the south and north directions. Both Zones II and III exhibited an average cool rate of $0.5^{\circ} \mathrm{C}$ in the HWP season, as shown in Fig. 5b), whereas Zone I showed a rising gradient of up to $2^{\circ} \mathrm{C}$. Central parts of Zones II and III showed an increase rate of temperature from $0.2-1^{\circ} \mathrm{C}$ in the SWM season (Fig. 5c). Few parts of the CRD region, viz. northeast, south and southwest corners, showed some cooling trend. The upward trend of temperature was observed for the NEM season in all zones up to $1.5^{\circ} \mathrm{C}$ (Fig. 5d). Other seasons had evidently shown rising trends throughout the CRD region, except for HWP temperatures. The spatial seasonal temperature changes showed that the central regions of the CRD area were in an upward trend.

\section{Spatiotemporal Trends of Extreme Indices}

The temperature extreme indices, Maximum Tmax (TXx), Minimum Tmax (TXn), Maximum Tmin (TNx) and Minimum Tmin (TNn) were calculated to obtain extreme values of maximum and minimum temperature recorded over the study period. TXX and TXn were considered indices of daytime, while TNx and TNn were considered indices of nighttime.

Most of the stations of the CRD region were observed with an upward rate of daytime indices (TXx,
TXn) than nighttime indices (TNx, TNn). These indices showed a positive trend (Fig. 6 a-d). Decadal increasing trends of TXx, TXn, TNx and TNn were observed at $1.03^{\circ} \mathrm{C}, 0.47^{\circ} \mathrm{C}, 0.44^{\circ} \mathrm{C}$ and $0.65^{\circ} \mathrm{C}$ respectively. More than $29 \%$ of the stations showed a statistically significant increasing trend, whereas $86 \%$ of the stations showed positive trends for TXx (Fig. 7a). The positive trend of TXn was observed in $71 \%$, in which $21 \%$ of the stations showed significant range (Fig. 7b). Both TNx and $\mathrm{TNn}$ showed a significant increasing trend than TXx and TXn. TNx was significant in $43 \%$, whereas TNn was significant in $36 \%$ of the stations (Fig. 7c-d). In addition to these four indices, high-temperature days (SU25) and diurnal temperature range (DTR) were also calculated. SU25 showed a positive trend with the least rate of 0.005 per decade (Fig. 6e). This implied that the Tmax was higher than $25^{\circ} \mathrm{C}$ in all the stations across the CRD region. The DTR showed an upward trend over the study years. As shown in Fig. 6f), except for a few stations, $72 \%$ of stations showed an average linear slope of 0.07 , which corresponded to a $0.52^{\circ} \mathrm{C}$ increase per decade. It was very evident from the calculated indices that the entire CRD region was experiencing a temperature warming trend.

The CSDI showed decreasing trends over most of the parts of the study area (Fig. 7f). An average negative slope of 0.26 was observed over the study area, with a decrease of -1.68 days per decade, except some 

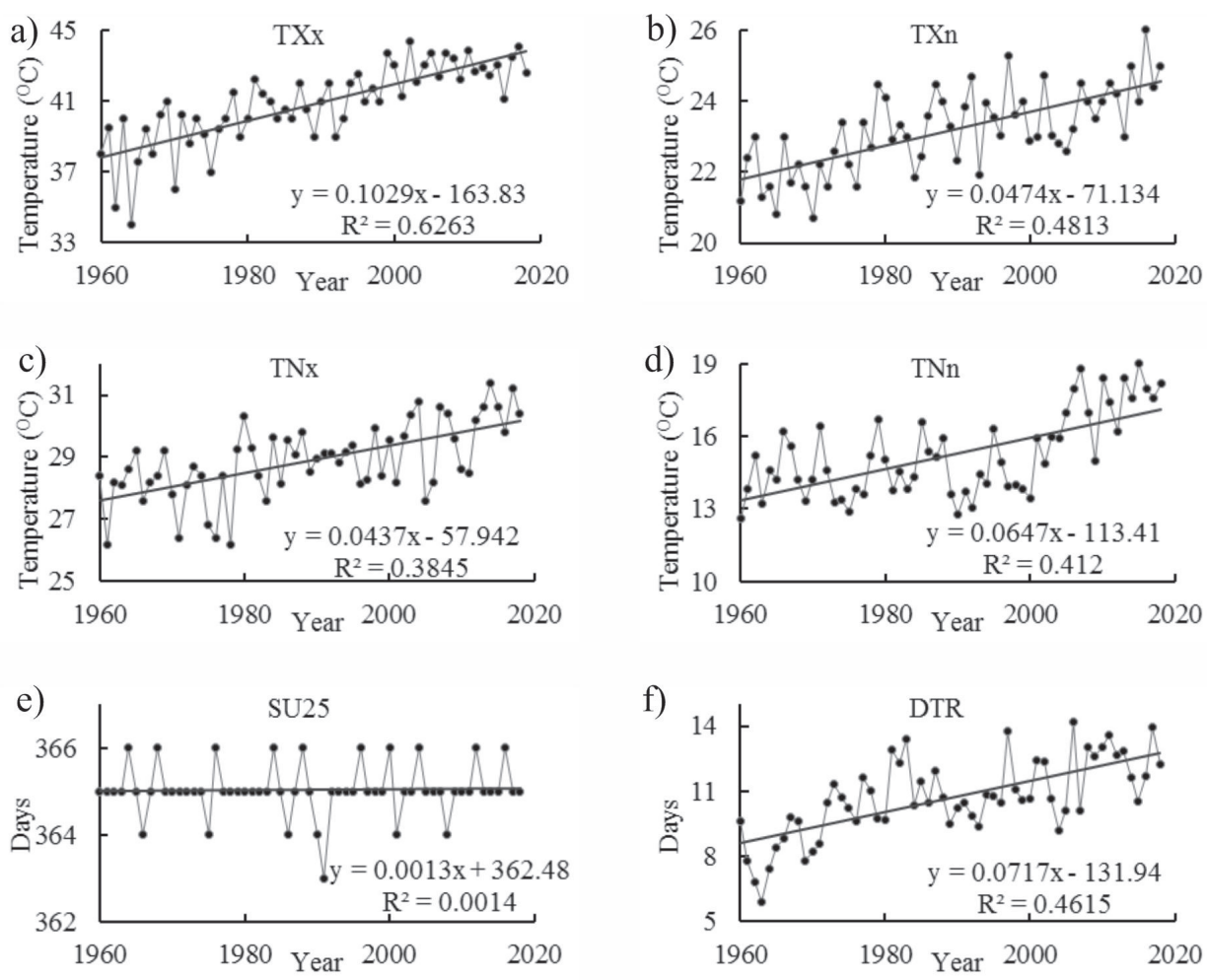

Fig. 6. Temporal trends of temperature extreme indices for the period 1960-2018 in the CRD region. a) Maximum of Tmax, b) Minimum of Tmax, c) Maximum of Tmin, d) Minimum of Tmin, e) High temperature days with $>25^{\circ} \mathrm{C}$, f) Diurnal temperature range.

stations near the coastal region, while others showed significant downward trends. The years 1990, 2006 and 1984 were recorded with higher values of CSDI. The WSDI showed a statistically significant increasing trend over $86 \%$ of the stations (Fig. $7 \mathrm{~g}$ ). Linear slope of 0.23 was exhibited with an increase of 1.54 days per decade. The higher values of WSDI were recorded for the years 2003, 2013 and 2017. It was observed from the calculated CSDI and WSDI that the CRD region has shown a significant warming trend over the study years.
Regarding spatial temperature changes in the CRD region, particularly in the central region and neighboring areas, we observed that the important upward trends both in annual and seasonal temperatures were mainly related to rapid urbanization. The significantly rising temperature trend would result in soil moisture changes and reduced water availability for plants [34]. Missing seasonal rainfall along with an increase in warming might easily result in drought and further reduce crop production [35]. The increased minimum temperature a)

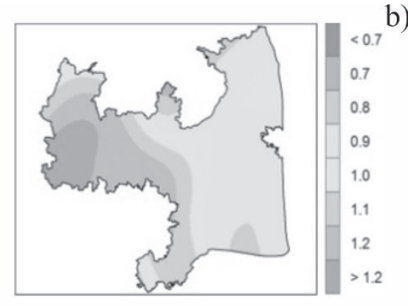

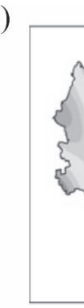

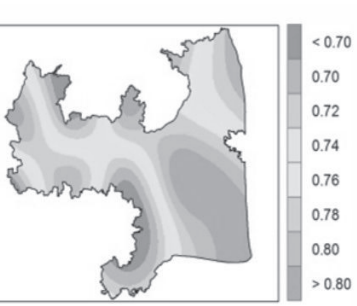

c)

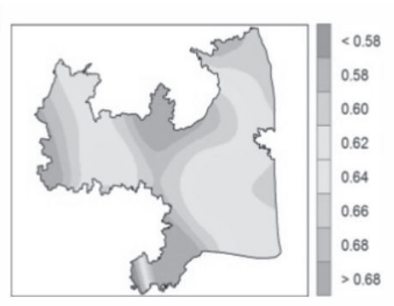

d)

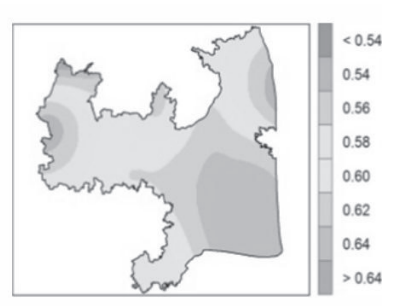

e)

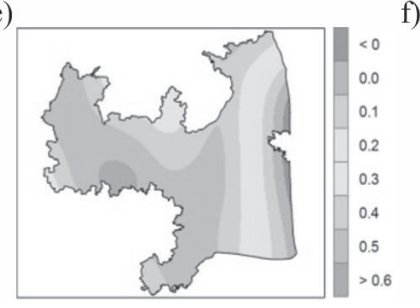

f)

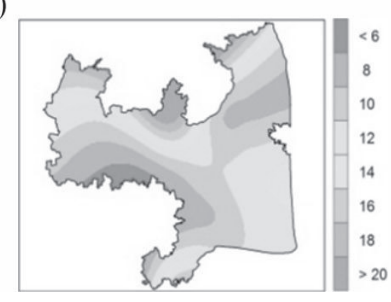

g)

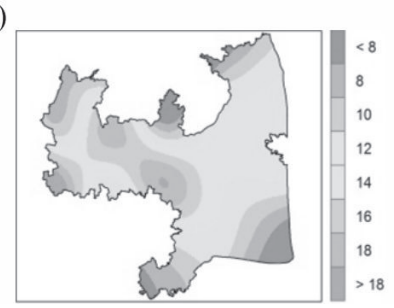

Fig. 7. Spatial trends of temperature extreme indices for the period $1960-2018$ in the $\mathrm{CRD}$ region: a) $\left.\mathrm{TXx}\left({ }^{\circ} \mathrm{C}\right), \mathrm{b}\right) \mathrm{TXn}\left({ }^{\circ} \mathrm{C}\right)$, c) $\mathrm{TNx}\left({ }^{\circ} \mathrm{C}\right)$, d) TNn $\left({ }^{\circ} \mathrm{C}\right)$, e) DTR (days), f) CSDI (days), g) WSDI (days). 
would affect productivity considerably. It was clear that continuous warming in the CRD region has important implications for other aspects also.

\section{Conclusion and Policy Implications}

In the annual, seasonal and extreme temperature scales for the study period 1960-2018 were analyzed for spatiotemporal temperature variability in the Cauvery River Delta (CRD) region. Both the MannKendall Trend Test and Theil-Sen Slope estimator were used to analyze the trend of indices of extreme temperature. In most parts of the study area (especially after the second decade), a long-term warming trend was seen between 1971 and 1980. 92.36\% of the stations showed a significant increasing trend at 0.005 level of significance. The CRD region recorded an increase of $0.4^{\circ} \mathrm{C}$ per decade in annual temperature. The results of the seasonal trend analysis revealed the fact that the entire CRD region exhibited a warming trend in all four seasons, whereas the CWP and HWP showed a maximum uptrend rate of $0.42^{\circ} \mathrm{C}$ per decade. The extreme temperature indices showed upward trends in both maximum $\left(1.03^{\circ} \mathrm{C} /\right.$ decade $)$ and minimum $\left(0.65^{\circ} \mathrm{C} /\right.$ decade $)$ temperatures. The increasing trend of WSDI showed an upward rate of 1.54 days per decade. It was obvious from this investigation that the CRD region showed a significant warming trend over the study years. The findings of the present investigation demonstrated that the spatiotemporal temperature variability of the CRD region was mainly due to the urbanization, geographical differences, interdecadal variation of monsoon season and global warming trends. It is highly vulnerable to climate change due to its important geographical location. This thorough estimation of temperature and extreme changes throughout the CRD region can help to develop and activate adequate irrigation and crop-changing strategies to protect vulnerable ecosystems from degradation.

According to a report based on climate model projections, the mean annual temperature rise of the current decade is around $0.4^{\circ} \mathrm{C}$ [36], which coincides with the results of the present investigation. However, trends of extreme indices have revealed that this region could face significant temperature variability and worsening agricultural practices in the next decades. The potential to adapt temperature variability would rely on the capacity to accurately track and adapt a series of changes. Thus, policymakers have to (i) prioritize the design of policies to track climate conditions, (ii) ensure a sustainable agricultural practice across the CRD region and (iii) identify adverse effects of climate variability in order to be incorporated into the frameworks in formulating agricultural and environmental policy. As human activities are the main drivers of climate variability, it must be investigated at the local and regional levels rather than at the national level such that adaptation initiatives are built for the resilience of farmers. Furthermore, in agricultural research, engineering improvement in crops and its cultivation methods are to be enhanced so that this can be achieved. This investigation was an attempt to understand the spatiotemporal characteristics of a single climate variable, i.e., temperature. Furthermore, this research could be enhanced in the future by the use of other relevant climatic parameters.

\section{Acknowledgements}

The authors are grateful to the working group of Expert Team on Climate Change Detection and Indices (ETCCDI) for providing Climdex software for extreme indices calculation. The authors also thank the US Environmental Protection Agency for making the ProUCL software freely accessible. The authors extend their gratitude to the editor of PJOES and anonymous reviewers for their professional and valuable comments and suggestions which are greatly helpful for further quality improvement of this manuscript.

\section{Conflict of Interest}

The authors declare no conflict of interest.

\section{References}

1. SCHOOF J.T., ROBESON S.M. Projecting changes in regional temperature and precipitation extremes in the United States. Weather and Climate Extremes. 11 (1), 28, 2016.

2. HEGERL G.C., ZWIERS F.W., BRACONNOT P., GILLETT N.P., LUO Y., MARENGO ORSINI J.A., NICHOLLS N., PENNER J.E., STOTT P.A. 2007: Understanding and Attributing Climate Change. In: Climate Change 2007: The Physical Science Basis. Contribution of Working Group I to the Fourth Assessment Report of the Intergovernmental Panel on Climate Change [SOLOMON, S., Qin, D., Manning, M., Chen, Z., Marquis, M., Averyt, K.B., Tignor, M., Miller, H.L. (eds.)]. Cambridge University Press, Cambridge, United Kingdom and New York, NY, USA.

3. PALANISWAMI S., MUTHIAH K. Change point detection and trend analysis of rainfall and temperature series over the vellar river basin. Polish Journal of Environmental Studies. 27 (4), 1673, 2018.

4. CHAUDHARI H.S., POKHREL S., SAHA S.K., DHAKATE A., HAZRA A. Improved depiction of Indian summer monsoon in latest high resolution NCEP climate forecast system reanalysis. International Journal of Climatology. 35 (10), 3102, 2015.

5. CALOIERO T., BUTTAFUOCO G., COSCARELli R., FERRARI E. Spatial and temporal characterization of climate at regional scale using homogeneous monthly precipitation and air temperature data: an application in Calabria (southern Italy). Hrdrology Research. 46 (4), 629, 2015. 
6. ZIERNICKA-WOJTASZEK A., KRUŻEL J. The diversification of air temperature trends in Poland (1981-2010). Polish Journal of Environmental Studies. 25 (5), 2205, 2016.

7. ZHENG H., CHEN Y., PAN W., CAI Y., CHEN, Z. Impact of land use/land cover changes on the thermal environment in urbanization: A case study of the natural wetlands distribution area in Minjiang river estuary, China. Polish Journal of Environmental Studies. 28 (4), 3025, 2019.

8. LACETERA N. Impact of climate change on animal health and welfare. Animal Frontiers. 9 (1), 26, 2019.

9. ZHANG Y. On the climatic uncertainty to the environment extremes: A Singapore case and statistical approach. Polish Journal of Environmental Studies. 24 (3), 1413, 2015.

10. ASIAN DEVELOPMENT BANK. Report and Recommendation of the President to the Board of Directors Proposed Loan India: Climate Adaptation in Vennar Subbasin in Cauvery Delta Project. 2016.

11. GOVERNMENT OF INDIA. Press Information Bureau. National Water Mission under National Action Plan on Climate Change. 2011.

12. JASWAL A.K., PADMAKUMARI B., KUMAR N., KORE P. A. Increasing trend in temperature and moisture induced heat index and its effect on human health in climate change scenario over the Indian sub-continent. Journal of Climate Change. 3 (1), 11, 2017.

13. ANNAMALAI H., PRASANNA V., HAFNER J., UDAYA SEKHAR NAGOTHU N.O.K. Modeling the current and future climate over the Cauvery river basin. In: Sustainable rice production on a warmer planet. Sustainable Rice Production on a Warmer planet. 1 (1), 59, 2011.

14. NAMBI A.A., BAHINIPATI C.S. Adaptation to climate change and livelihoods: An integrated case study to assess the vulnerability and adaptation options of the fishing and farming communities of selected east coast stretch of Tamil Nadu, India. Asian Journal of Environment and Disaster Management. 4 (3), 297, 2012.

15. DHANDAPANI R., JAGANNATHAN R., GEETHALAKSHMI V. Comparative performance of RegCM model versions in simulating climate change projection over cauvery delta zone. International Journal of Science and Technology. 6 (8), 5115, 2013.

16. BAL P.K., RAMACHANDRAN A., GEETHA R., BHASKARAN B., THIRUMURUGAN P., INDUMATHI J., JAYANTHI N. Climate change projections for Tamil Nadu, India: deriving high-resolution climate data by a downscaling approach using PRECIS. Theoretical and Applied Climatology. 123 (3), 523, 2015.

17. BHUVANESWARI K., GEETHALAKSHMI V., LAKSHMANAN A., SRINIVASAN R., UDAYA N. The impact of El Niño / Southern Oscillation on hydrology and rice productivity in the cauvery basin, India: Application of the soil and water assessment tool. Weather and Climate Extremes. 2 (1), 39, 2013.

18. RAMACHANDRAN A., PRAVEEN D., RADHAPRIYA P., DIVYA S.K., REMYA K., PALANIVELU K. Vulnerability and adaptation assessment a way forward for sustainable sectoral development in the purview of climate variability and change: Insights from the coast of Tamil Nadu, India. International Journal of Global Warming. 10 (1/2/3), 307, 2016.

19. VIJAYASARATHY K., ASHOK K.R. Climate adaptation in agriculture through technological option: Determinants and impact on efficiency of production. Agricultural Economics Research Review. 28 (1), 103, 2015.

20. RAMACHANDRAN A., PRAVEEN D., JAGANATHAN
R., PALANIVELU K. Projected and observed aridity and climate change in the east coast of South India under RCP 4. 5. The Scientific World Journal. 2015.

21. ASIAN DEVELOPMENT BANK: CONSULTANTS' REPORTS. Climate adaptation through sub-basin development investment program cauvery delta zone: Climate data and future scenarios-Final Report. 2013.

22. SAMIAPPAN S. Impact of regional climate model projected changes on rice yield over southern India. International Journal of Climatology. 38 (6), 2838, 2018.

23. KINGWELL-BANHAM E. Dry, rainfed or irrigated? Reevaluating the role and development of rice agriculture in iron age-early historic South India using archaeobotanical approaches, Archaeological and Anthropological Sciences. 11 (12), 6485, 2019.

24. KOTHAWALE D.R., RAJEEVAN M. Monthly, seasonal and annual rainfall time series for all-India, homogeneous regions and meteorological subdivisions: 1871-2016 Indian institute of tropical meteorology ( IITM ) Earth system science organization (ESSO) Ministry of Earth Sciences. 2, 1871, 2017.

25. REPORT OF NATIONAL WATER DEVELOPMENT AGENCY, INDIA. Water Resources and Hydrology. 2017.

26. YE Z., LI Z. Spatiotemporal variability and trends of extreme precipitation in the huaihe river basin , a climatic transitional zone in East China. Advances in Meteorology. $1,2017$.

27. OZTURK D., KILIC F. Geostatistical approach for spatial interpolation of meteorological data. 88, 2121, 2016.

28. SALAMEH A.A.M., GÁMIZ-FORTIS S.R., CASTRODÍEZ Y., ABU HAMMAD A., ESTEBAN-PARRA M.J. Spatio-temporal analysis for extreme temperature indices over the Levant region. International Journal of Climatology. 1, 2019.

29. LI S.H., JIN B.X., ZHOU J.S., WANG J.L., PENG S.Y. Analysis of the spatiotemporal land-use/land-cover change and its driving forces in Fuxian Lake watershed, 1974 to 2014. Polish Journal of Environmental Studies. 26 (2), 671, 2017.

30. PANAITESCU L., ILIE C., POPESCU M., LUNGU D., NITA S. Modern approach to the phenomenon of drought and aridity in Central and South Dobrudja. Journal of Environmental Protection and Ecology. 15 (1), 110, 2014.

31. KEGGENHOFF I., ELIZBARASHVILI M., KING L. Trends in daily temperature and precipitation extremes over Georgia. Weather and Climate Extremes. 4, 75, 2014.

32. ALHAJI U.U., YUSUF A.S., EDET C.O., OCHE C.O., AGBO E.P. Trend analysis of temperature in Gombe State using Mann Kendall trend test. Journal of Scientific Research and Reports. 20 (3), 1, 2018.

33. PATIL S.G. Application of change point analysis (CPA) to monthly temperature in Tamil Nadu, India. Mausam, 70, 3, 561, 2019.

34. LI Z., XIE C., CHEN D., LU H., CHE S. Effects of land cover patterns on land surface temperatures associated with land use types along urbanization gradients in shanghai, China. Polish Journal of Environmental Studies. 29 (1), 1, 2019.

35. MATIU M., ANKERST D.P., MENZEL A. Interactions between temperature and drought in global and regional crop yield variability during 1961-2014. PLoS ONE. 12 (5), $1,2017$.

36. SARAVANAKUMAR V. Impact of climate change on yield of major food crops in Tamil Nadu, India. South Asian network for development and environmental economics. 2015. 